\title{
Visions of the Spanish Revolution: identities and conflicts in post-welfare societies
}

\author{
Visiones de la "Spanish Revolution": identidades y conflictos en las \\ sociedades del posbienestar
}

\author{
Antonio Alaminos-Chica / alaminos@ua.es \\ Clemente Penalva-Verdú / clemente.penalva@ua.es \\ Universidad de Alicante, Spain
}

\begin{abstract}
This is a case study that analyzes photographic documents of the social protest in Spain between 2011 and 2013. The analysis is qualitative and considers the use of space, the visual expression of the messages and the orientation toward the causes or effects of political, economic and social changes. Visual sociology allows us to appreciate, in the case of the Spanish Revolution, a dynamic of "reflexivity" unrecognizable from other research approaches.

Two successive waves of social mobilization in response to two different shocks can be appreciated. The first is given by political corruption, unemployment and the threat to consumer society. The second shock is caused by the savage cuts in the Welfare State. Social mobilization is expressed differently in each phase, and the forms taken by the protests show how the class structure in post industrial society shapes the reactions to the crisis of the Welfare State.
\end{abstract}

Key words: social movements, Spanish Revolution, visual sociology, social structure, welfare crisis.

Resumen: Este es un caso de estudio que analiza los documentos fotográficos de la protesta social en España entre 2011 y 2013. El análisis es cualitativo y considera el uso del espacio, la expresión visual de los mensajes y la orientación de los mismos hacia las causas o efectos de la política y de los cambios económicos y sociales. La sociología visual nos permite apreciar, en el caso de la Revolución Española, una dinámica de "reflexividad" irreconocible a partir de otros enfoques de investigación.

Se pueden apreciar dos oleadas sucesivas de la movilización social en respuesta a dos diferentes shocks. El primero lo produce la corrupción política, el desempleo y la amenaza a la sociedad de consumo. El segundo es causado por los recortes salvajes en el Estado del Bienestar. La movilización social se expresa de forma diferente en cada fase, y las formas que va adoptando la protesta muestra cómo la estructura de clases en la sociedad posindustrial configura las reacciones a la crisis del Estado de Bienestar.

Palabras clave: movimientos sociales, Spanish Revolution, sociología visual, estructura social, crisis del Estado de Bienestar. 


\section{Introduction $^{1}$}

There are social realities which are only accessible through the images they offer. In these cases visual resources, taken as data generated by society, fulfil the functions of illustration and comprehension. Visual sociology allows integrating these data types with the theories under discussion, thus enabling a better understanding of social phenomena; the latent processes are not always conceptually manifested. This is the case of the so-called Spanish Revolution. The Spanish Revolution started with pacific concentrations in 'Puerta del Sol' in Madrid on 15 May in 2011. It was a spontaneous concentration, which progressively add more and more people, until establishing a camp. This initiative spread throughout Spain and was imitated in many cities and towns. The speed of imitation is explained to the extent that social unrest was shared by most of Spanish people and gave a response to both the causes and the consequences of the crisis.

$15 \mathrm{M}$, as a social platform, is still active today in many cities and supports and promotes all protests gathered in 2011 at Puerta del Sol. This way, $15 \mathrm{M}$ supports the claims of more democracy, against evictions and all those protest against trimming of the welfare state (health, education, etc...). They keep the spirit of the moment of that collective protest. However, as it is seen by visual analysis, protests have changed showing specialized styles of action and expression.

Spain has lived, in just a decade, a period of unprecedented economic expansion, followed by another period of crisis and deep depression. The consequences have been immediate due to the intensity of the crisis. The speed with which unemployment has grown and the cuts in social spending have been a real shock to Spanish society. Spanish society had experienced for decades an ongoing process of upward intergenerational mobility, which for the first time is seriously threatened. The history of the Spanish social structure of the past 50 years is the story of a middle class that includes more and more people. And it is especially important, both objectively and subjectively. The identification with the lower middle class absorbs much of the people who had been coded previously as workers, at the stage of the Spanish transition

1 This work was supported by the European Commission under grant FP7-PEOPLE2012-IRSES. CIVIL-SW. Civil Engagement in Social Work: Developing Global Models. Project Coordinated by University of Coventry. Research Team University of Alicante: M.A. Martínez-Román, A. Alaminos Chica, MA. Mateo Perez, Y. López Domenech, C. Penalva, and J. Tortosa. Duration: 36 months. 
to democracy. In Spain, the expansion of the middle classes is relatively recent and on average reaches two generations.

A distinctive and highly significant element of modern theories of social structure is the expansion of the middle classes. Middle classes linked to the processes of urban concentration and growth in service economy have facilitated social support for developed democratic societies. There are many indicators of social class (education, occupation, cultural capital, etc.) although one of the most significant, in terms of social peace, is the subjective perception of belonging to the middle classes. This element of subjective affiliation is an ideological anchor that avoids violent performances. The Spanish want to remain what they think they are (middle class thanks to the welfare state) and try to avoid change. In that sense, social conflict emerges due to conservative reactions oriented to keep social achievements. These social movements are oriented to keep and not to change the 'status quo'.

First, we briefly consider some concepts that frame the understanding of developed societies. Those concepts frame the posterior visual analysis. If the theories about middle classes, welfare, identities and reflexivity are right, the reactions against the threats to welfare state could produce new forms of identity and social consciousness. After explaining the usefulness of visual sociology to describe and understand certain social processes that can only be identified by this methodology, the article undertakes the task of differentiating two clear distinct sources of motivation of the protest and their respective forms of participation, establishing their sequence and articulation between them.

\section{Reflexivity. Classes and identities in the Spanish Revolution}

The actual conflicts in Spain do not respond, ideologically, to a class struggle in the terms originally proposed by Marx but belong to the debate about the nature of the class structure and the changes that had taken place in developed societies over the past 60 years. There is important agreement among sociologists about the relevance of middle classes in the configuration of contemporary social structure. This social class unexpected by Marx, changes the structure of the conflict. The expansions of middle classes (in plural) have a close connection with the old proposal about 'embourgeoisiement' and the current social conflicts. The idea of 'embourgeoisiement' was developed in the fifties as a process that asserted that Western European societies were moving toward a new social structure. 
One characteristic of these new classes was its multiple segmentations. As Raymond Aron (1964: 356) wrote many years ago, the 'bourgeoisie' is 'not a coherent unity'; the middle classes constitute 'a kind of hold-all' in which individuals are placed if they cannot be put into any of the other classes. Especially when, in order to explain social conflict the Marxist approach is used. But this heterogeneity is not a consequence. As Dahrendorf (1959) pointed out, the new middle class was born decomposed. That original decomposition indicated by Dahrendorf was accentuated by the progressive overlap between consumption and identity. Consumption is what defines membership, expressing specific lifestyles. In Spain, until recently, it has still been possible to observe how the identification with middle classes was rooted more in consumption than in production (Alaminos and Penalva, 2011). The dynamic of consumer segmentation by lifestyle has imposed a dynamic of social disintegration (identity by lifestyle). What originally the brands unified (membership), in the last stage of the development of the consumer society, the notions of lifestyles segmented society.

Today, in the Spanish case, the survival of the middle class (with a membership more subjective than objective) depends on the welfare state. This is especially true, after a strong increase in unemployment and the deteriorating quality of jobs due to labor reform (Alaminos and Penalva, 2013 and 2014). The welfare state is the main tool to remain in the middle class, once that so many jobs have been destroyed at high speed. Under these conditions, the permanence of the welfare state is essential to help unemployed to identify with middle class in Spain. If a child cannot study due to lack of resources, or does not have medical care, for example, it is difficult for their parents to continue considering themselves middle class, even more in the case of being evicted from their home.

Indeed, the analysis of this situation in Spain hides something fundamental. This is one of the most interesting contributions from visual sociology: it helps to identify the change that suffer the social movements in Spain. Thanks to visual sociology we can clearly recognize and identify two waves in what initially appears as a single phenomenon. This change, the different natures of the social reactions to two different shocks, cannot be fully appreciated by means of traditional methodologies, like for example, social survey or interviews.

And this is a key idea. The middle classes in Spain have experienced two successive shocks. Firstly (in the essence of $15 \mathrm{M}$ ), we found the loss of the identity anchored in consumption due to the explosion of unemployment. That unrest ultimately led, as it can be visually seen, to a generic protest. 
A protest that contained multiple claims and complaints. This first shock (unemployment and collapse of consumption) took place under a socialist government. The second shock comes from the hand of the conservative government, which focused on the reduction of the welfare state.

But the collapse of the welfare state involves the collapse of the identification with middle class by the majority of society. In the wreck of unemployment and welfare, there are few objective or emotional elements to keep the idea of being middle class. There are obvious risks on the collapse in identification with the middle classes. At the same time, the social reactions were fueled by the scandals of political corruption and misuse of public money. In fact, there are three trends that have hit in Spain at the same time: the economic crisis (unemployment), the social crisis (dismantling of the welfare state and collapse of consumption) and the political crisis (corruption). The new policies which reduce welfare are seen as an abuse of politicians, showing their dependence on the economic powers.

Spanish society is now living a new transition. So far, the protests have been peaceful; unlike the expression of the protests in other countries experiencing political crisis, economic and social, like Greece for example, Spanish protests were always peaceful and relied more on mobilization and reasoning than on violent action. This feature is a consequence of the fact that ideologically protests are mostly a 'conservative' reaction oriented to maintain the previous welfare state; the fear of losing social status is what governs the process. In that sense, violence is not part of the picture that the middle class has of itself. Acting violently would be the main sign of being out of the middle class; this is, with the excluded ones.

In this context, an important question is how a fragmented middle class without class-consciousness becomes aware of its existence and starts to act. In a way, the Spanish revolution was a consequence not foreseen by the initial claim: protest the Sinde law regulating online downloads. It was the effects of reflexivity, in the terms of 'reflexive modernity' (Giddens, 1991), which facilitated the process.

Reflexive modernity operates at two levels, structural and individual. At the structural level, new social forms are experienced. New social forms shaped by transformations caused by modernity. This modernity replaces the industrial society by a society of risk. (Beck, 1994). Simultaneously, at the individual level, there is a loss of identity referents. In simple modernity, the identity of individuals came from work, family and school. Those identities were relatively fixed. Now, in reflexive modernity, the instability 
of identity referents - Liquid Modernity (Bauman, 2000) - individuals must build their own autobiography.

In Giddens' terms (1994), the construction of the self occurs as a reflex product. Individuation becomes another character. Against the concept of autonomy (consciousness, independence and freedom, which are part of the Enlightenment), the contrasts of individual responsibility, since individuals are responsible for their decisions and life histories. Given these conditions, a basic feature of reflexive modernization is the replacement of identity reference based on social class (marked by work and training) by lifestyle (supported mainly by consumption).

Here is where the media have an important role. They spread lifestyles and behavioral patterns constantly changing. This amplifies the contradictory effects of the processes of socialization. The individuals involved in specific groups and fragile communities found in the media (especially with social networking technology), a resource to meet the need of creating new identities.

The concept that gives meaning to these processes which operate reflexively in modernity is 'ambivalence. This ambivalence emerges between the idea of development (industrial, technological, social) and risk (ecology, science, technology, work, inequality), and also amidst the deepening of globalization and the expansion of individualism.

Indeed, the media enabled the Spanish Revolution of 2011 to be a step in the overall path of social protest that has swept the world in recent years. A global phenomenon of reflexivity, which began in North Africa in the 'Arab Spring' in late 2010 and which went through Europe and across the Atlantic with the Occupy Wall Street (2011), and the movement and protest of Istanbul and Brazil in 2013.

In 2011, the first concentration in Puerta del Sol had a heavy impact on national and international mass media. Mass media followed these concentrations day after day. Televisions made a continuous monitoring and connections at primetime. Concentrations were made shortly before local and regional elections, so its expected effect was high. In fact, an important part of their success was the 'mirror effect' that televisions, press and radio had produced in the Spanish society. The theoretical concept of reflexive society showed all its potential. Many Spaniards identified themselves (in spirit) with those concentrated in the squares of hundred of Spanish cities. The mass media created a circle of expectations. The feeling and emotions grew in that context. Emotions and empathy are the main descriptor of that phase. 
Reflexivity, understood as the knowledge and awareness that society take of their actions, especially due to the mass media (including the Internet), has been a central element that triggered recent processes in North Africa. Reflexivity acts fast in current developed societies. In the process of reflexivity there is an intense 'feedback' between effects and causes, so that in its expansion process generates a lack of differentiation between them. This property of 'reflexivity' is increasing today, becoming part of the generation of individual identity. Thus, Giddens (1994) postulates that 'reflexive modernity' reflects the increase of self-consciousness of individuals and society, and how it affects the image generated by the actions carried out. This process of reflexivity has acted in the Spanish revolution at the two levels proposed by Giddens. Society's awareness of their actions will feedback their future behaviors. This dynamic has operated actively in the Spanish Revolution, especially fueled by new technologies and the privileged attention the media gave to the protests. Since the beginning of the economic crisis and the dismantling of the welfare state, in Spain the media lived in the expectation that something was going to happen.

The start of the protests was fed by the media attention and positive perception of the claims reflected there. If anything characterizes the Spanish Revolution and its development in later years is its deeply visual nature thanks to its media treatment. The introduction of the protests into the agendas of the media has been one of the greatest achievements of the protests. Those concentrations were favored by their peaceful nature. These protests had quick and wide international influence, inspiring others like 'Occupy Wall Street' in New York. 15M became a symbol of the protest against the political response to the financial crisis.

\section{Visual analysis of the social responses to the welfare crisis}

In this phase of the social conflict, the contribution from visual sociology is essential. What visual sociology? In this research we will consider the images of the social protest as data. The visual data show the reactions of Spanish society to the economic crisis. From a qualitative approach, visual sociology helps to explore the conditions that shape social phenomena through the forms it takes. Only the visual approach may help to identify the process followed by the $15 \mathrm{M}$ protests and its theoretical coherence. The visual elements are data that allow us to recognize and understand the nature of the process, at the same time that it acts like registers and memories. The visual elements of this research come from photographic documents that 
have been self-produced by the participants themselves or come from the coverage of the mass media. Photography has been widely used in the field of visual sociology, usually based on the assumption that they are signs that lead directly to the reality they describe due to their high degree of similarity between the sign and iconic object. From such perspective, incorporating visual indicators is as legitimation for the production of knowledge as words and numbers. And in this case, it is particularly useful for both the description and understanding of a process (social mobilization in Spain) and for the representation of such an abstract theoretical concept as that of reflexivity in contemporary societies. The photographs, in their ability to establish themselves as indices, point to a reality (what images represent) as signifiers, and at the same time, these signifiers help the researcher to induce their social meaning.

What data? The first thing to consider is the nature of the data, the visual materials used. First, the data used here do not fit neatly into the reference poles considered by Pauwels (2011). On the one side, visual material whose production are beyond the control of the researcher and are usually anonymous ('found materials'); and on the other side, the visual material produced by the researcher. The visual material used here has been produced by society itself. In many cases, the producer of the images is identifiable: press, citizens, TV channels, Internet, associations and social media. In that sense, we may say that the images are 'found materials' but with known origins. The images of the Spanish Revolution used here come from different sources, highlighting those taken by the participants in the demonstrations. Although the image review was carried out using these sources, images to which we refer in this text are those pictures (not including motion pictures) showing a substantial ability to become visual indicators of the social phenomenon we are studying: the transformation process experienced by the protests, and especially, its identity expression in terms of social class. Since it is impossible to reproduce every analyzed document (due to the large amount and because some are protected in terms of copyright), the documents cited in the presentation of the results are a selection based on their relevance and significance.

In fact, there is a huge similarity between visual indicators extracted from the photographs of mass media (digital editions of newspapers with national coverage) and those which are self-production product of the participants in protests (exposed mainly in social media). In practice, the two documentary sources act as a triangulation on the data. This triangulation offers greater validity to the use of the images as indicators to measure social change. 
We believe that in terms of heterogeneity, the selection of visual documents is representative of the type of images present in the protests. Diversity is ensured by including a dual view: the point of view of an institutional social actor (the mass media) and the perspective of the participants of the protests. In both selection processes, information reaches the saturation point very quickly; that is, the main visual indicators of the social fact which they represent appear repeatedly. Both journalistic observers and demonstrators granted representativeness and significance to the same images. Images appear as an expression of what the participant observer believed to be emphasized. The photos point to what really matters, and in this case, there is a saturation of images that are repeated with the same contents. Indeed, in qualitative research, saturation is together with diversity, the most important criterion at the moment of defining when to finish the execution of a sampling design. The fact of analyzing a portion of social reality characterized by its visual culture, where images are ubiquitous, facilitates on the one hand the production of graphic evidence on many facets of everyday life by social actors; and, on the other, it facilitates the location of many documents related to the topic investigated by the researcher.

As warned by Chauvin and Reix (2013), the limitations of validity and reliability of visual information are basically the same as those with the observational methods. Fiver are particularly noteworthy: 'la perturbation des interactions par l'observateur', 'les effets de la mise en scène de soi par les enquêtés', 'la construction d'une relation de confiance avec les enquêtés', 'le problème du droit à l'image' and 'le risque de surinterprétation des images'. Of these five, only the last two have significant relevance in this research. If we consider the question about the rights of the visual material we can observe that there is a part of the available visual material that is copyrighted. This represents a minor difficulty, given the presence of thousands of images available, most for public use. About the second threat we can only try to control it by the appeal to the theory. The interpretation makes sense if the existing theoretical proposals provide consistency between the image and its interpretation. Nevertheless, its exploratory qualitative basis has the same difficulties as the rest of qualitative research, such as interviews, focus groups or observation, for example. Over-interpretation is a concern in any analysis. In any case, the presence of reflexivity affects the methodology, as it provides a potential bias in interpretation. However, from a methodological point of view, we believe that reflexivity that permeates this entire social phenomenon is an important element that helps in reading visual data. We consider with 
Bourdieu and Wacquant (1992) that reflexivity is part of the solution, not the problem.

In terms of reliability and validity, we have not made a selection or sampling of the images used. Indeed, as Conord (2002) rightly pointed, the process of production may condition the visual material. However, biases and difficulties found in other types of visual materials do not appear in this case. Among the thousands of images available, from professionals and amateurs, there is high consistency in the elements relevant to the investigation. The use of these records, given their abundance, allows validating their contents and minimizing the effect of the image construction. We are considering thousand of photos and videos, picturing the same reality. Considering the purpose of use of pictures and according to the classification of Chauvin and Reix (2013), our approach focuses on at least three of the five points they mentioned: off-road observation ('hors-terrain'), the expression of concepts through images ('mise en images de concepts') and the strength of the images ('the puissance of désignation des images').

\section{Visual data analysis}

In the analysis, we have developed a synchronic and diachronic reading of the images to document social change (Rieger, 2011). Thanks to the visual analysis, the existence of two phases in the process of protest that started in Spain in May 2011 is clear. The first wave of protests coincided with the beginning of the Spanish Revolution. The second wave started with the massive dismantling of the welfare state initiated by the Popular Party in December 2011. Thus the heterogeneity and proliferation of signs and messages of the first response (first wave) is replaced by the appearance of explicit segmentation, where each call demands a differentiated aspect. One of the most obvious visuals aspects in this second wave is the use of color.

In this case, the researcher has not made an explicit design to generate data to illustrate the change. How the reality and its photographs have evolved over time is which allow us to see clearly the changes. The forms that adopt the social reactions and the mobilizations shape the process of change. This longitudinal analysis allows us to identify two waves. Table $1^{2}$ summarizes the findings of the visual analysis of the social reactions, considered in a longitudinal approach.

2 Tables are in the Annex at the end of the article (Editor's note). 


\section{First shock: the power of reflexivity}

In its first moments, the Spanish Revolution was an unexpected consequence. Some groups called for a demonstration against the 'Sinde Law'; this law was one that regulated Internet downloads. But the answer to this call was wider and deeper than expected. From the beginning, the social reaction leaves aside the topic of the call and turned to more sensitive and fundamental subjects. Many people concentrated and remained at night in 'Puerta del Sol' in Madrid. Mass media started an incredible coverage, with TV emissions from the concentrations. Reflexivity acted in a quick and strong way. These concentrations that occupied the public squares were extended to most of the Spanish cities. The action of reflexivity and the role of the mass media were essential for the development of the Spanish Revolution. The Spanish Revolution was a visual revolution. The Spaniards could see on television that many others shared the same problems and a similar diagnosis of the crisis with them. The empathy was intense in a broad sector of the population.

Those concentrations on the May $15^{\text {th }}$ were a meeting point for diverse claims. Not all of them clearly compatible in their motivations or in their consequences. It can be observed in the slogans that were showed there. The majority of the protests formed 'totum revolutum'. The longitudinal analysis of the evolving forms of the protest allows us to produce a 'genealogical' analysis of the contents. But it also shows the meaning and motivation of actions. Thanks to visual sociology, it is possible to recover slogans and the forms of protest, which shows the latent structures of these social reactions.

In that sense, in the middle classes, ideological consciousness was based upon the lifestyles of consumer and welfare (Alaminos and Penalva, 2013). The increase of the welfare state in the eighties produced the expansion of the middle classes. The feeling of belonging to middle classes was defined by consumption and quality of life. But this process has arrived to an end and is reversed. Of course, now it is a question of quality of life but above all, it is a question of identity (individual and social). The Spanish Revolution does not emerge from class consciousness or conflicts articulated by occupations or production. The Spanish revolution has its roots in the middle classes formed in the last forty years.

The collapse of consumption (due to increased unemployment) destroyed the identities based on lifestyles. The last housing bubble had drained the capital resources of the middle and lower classes. With a high debt level, 
they depend critically on their work to keep their consumption. This is one of the main motivations behind the mobilizations. Therefore, to the extent that the first crisis affects lifestyle, the social reaction was oriented towards the causes of the economic crisis, including in it the waste and corruption of politicians. We managed to see slogans calling for the re-foundation of democracy (corruption and political alienation), and asking to reform capitalism (unemployment, economic crisis and evictions). In that regard, at Puerta del Sol, and with an apparent unity, there was deep and irreconcilable heterogeneity. In the same square, and peacefully, two currents co-existed. One current motivated by the decline of the middle class, threatened by unemployment, the collapse of consumption and associated lifestyles.

The second current, more traditional, linked to anti-system movements. In this case, the claims were oriented to the quality of democracy, consumer society and capitalist exploitation. In that sense, socially $15 \mathrm{M}$ contained contradictory souls. The economic crisis mobilized sectors of the population that had not been previously mobilized, together with other more committed to social change.

Reflexive modernization acted differently. For example, for the middle class at risk of decline, it appeared as a new element of self-awareness while, at the same time, produced a reinforcement of the interpretations that the middle classes gave to the causes of these new problems. For highly ideological citizens: environmentalists, anti-capitalists, etc., it was the opportunity to share and socialize their diagnosis. All those heterogeneities share space and mass media in the first moment. The subsequent development of the process will express the actual ideological limits and social conditions of the conflict. In fact, it shows an empirical link between the idea of 'modernization reflexive', and the forms that the protest may adopt in those societies experiencing the welfare crisis. The mass media and their impact on reflexivity will be decisive in post-welfare societies.

In response to the first shock, there were protests associated with specific problems. Manifestos and posters with 'slogans' were mainly used. The process to occupy Puerta del Sol in Madrid was possibly one of the few moments of convergence. It was the time for a process of collective deliberation, it identified in politics and politicians one of the essential keys of the problem. However, after this spatial convergence, subsequent developments of the protests adopted segmentation as a means of expression. 


\section{First wave's visual data}

We can find a set of Internet sites that collect a multitude of images relating to the rallies and demonstrations that took place on May $15^{\text {th }}$, 2011 and the following days. In most of them, we observe heterogeneity (age, identity, lifestyle) and textuality (marked with a strong presence of lyricism); and histrionics in the gestures of the social actors represented. The documentary graphic references are in Internet with topics as "Spanish Revolution", "AcampadaSol", "15M". The documents are photographs taken by professional journalists (newspapers, agencies); as well as images that came from the eyes of the protagonists of the protests, which were hosted by different social networks (Flickr, Facebook, Twitter) (see Table 2).

\section{Second shock: the end of welfare}

The second shock took place after the arrival of the right to the government. The conservative party introduced significant reductions of the welfare state. The government reduced spending on education, health, pensions, social services, etc. All these reforms produced a heavy impact on the quality of life and threatened the idea of belonging to middle class in a context of economic crisis. The crisis of the welfare state become an identity crisis. The social reactions to this second shock were different and include signs and forms that facilitate the idea of community. In the previous reactions, people defended their lifestyles in close connection with their subjective social position. Now, with the high cost of education or health, the risk of social descent is real.

In this moment of the process, the crisis of the welfare state has not produced conflicts articulated by social classes, from production or occupation. The main lines of resistance have been the pillars of the welfare state. These new lines of bourgeois protest are added to the old anti-capitalism lines that questioned markets and capitalism. At this second stage, the different calls are articulated by welfare sectors and social and political topics where the different claims that shown different forms and visual expression.

In that sense, the different demonstrations are now segmented. In those related with the crisis of welfare, providers and consumers of welfare are articulating the protest. The welfare pillars in the service sector have segmented the emerging conflicts. The deepness of the crisis might produce in the future a new social structure that will be expressed in various ways. But 
at the very beginning, social responses will be articulated by the impacts of the crisis on the different sectors of welfare. The demonstrators are the users and producers of welfare. They produce a segmented protest. Education, health, pensions, justice, social service produce their own monothematic demonstrations.

The segmentations of the protest are reinforced with visual elements. Each dimension of the protest uses a different color for identification: red (unemployed), orange (social services), white (health), green (education), black (civil servant) and yellow (justice). This is especially visual in the demonstrations. As we said, concentrations and demonstrations are monothematic and the attendees dress in the colors of the call. These colors stressed the dimensions affected by the crisis. Any other movement of protest feel a compulsion to choose one color to identify their claims. Colors and spaces are utilized to reinforce identity and belonging. All the movements in parallel with those related to the welfare crisis also use colors. For example, the 'Plataforma de Afectados por las Hipotecas' [Platform of the Affected by Mortgages, $\mathrm{PAH}$ ] used green and red, resembling a semaphore. The appeal to visual expressions is a constant in the Spanish Revolution.

In the second shock the presence of text is lower than in the first one. In many cases, there is a strong contradiction between text and images. For example, the picture of a demonstration where all participants wear the same color (that differentiates them from the other movements) with a poster that said 'Together we can'. The idea about joining forces does not fit with all these segmented demonstrations trying to defend the welfare in a separate way. The main reason is because they do not concentrate in the defense of welfare. They only defend one of the dimensions: for example, health or education. They defend the dimension that directly affects them. The social movements now tend to reduce arguments and concentrate in identifications.

One of the advantages of this combination of segmentation and internal homogeneity in the segment is the reduction of conflicts. Under the same colors, there are different ideologies, and fundamental cleavages are covered by the 'marks': green, black, and white... The colors reduce internal debate and concentrate on the damages to welfare. The colors unify and avoid internal debate. These colors expressed, in a simple way, the feeling of belonging to a collective. Both providers and users identify themselves by the use of a color.

There are multiple political ideologies: nationalist, left, right, liberal. The color hides the potential conflict. The color is an identity marker. These movements in defense of welfare are conservative, in the sense of thein 
intention to preserve the welfare state. All they need is the past. They do not try to build a new future. They only need a color to express what they want to keep. Just one color for what they want to recover. In this sense, community reactions cluster around these flags. The colors function as a silent system of identities that covers the differences. The colors used in T-shirts and hats stress the feeling of community.

\section{Second wave's visual data}

Similarly to the previous case (first wave), we have a set of Internet sites that collect images on protest rallies convened by the different "tides" organized and mobilized in the years 2012-2013 in Spain. By contrast with the first wave, we find homogeneity (colors), self-reference, lower presence of textuality (which is marked by the prosaic to the specific claims); and pose of the social actors represented. The documentary graphic references are on the Internet with topics related to the colors of the tides ("Black Tide", "White Tide", "Green Tide"). In the same manner as in the first wave, the documents were produced by conventional means, as well as by the protagonists (see Table 3).

Overall, colors act as identity systems: fragmented identities that reflect the relevance of the use (consumer) over production (labor) in the subjective definition of belonging. It seems that nowadays, in post-industrial societies, social responses to the effects of the crisis reflect the image of the social structure. We are far from masses of workers 'colored' by one ideology, fighting in a class conflict. In this case, colors (red, white, black, yellow, etc.) act like flags that disaggregate and reduce the real effects of the protest. This diversity looks like an impressive social reaction, in a visual sense. The real effects are the opposite: reduce their effects to change political decisions.

Another important difference is that in this second phase, the bulk of the movements are oriented to the consequences. There is less debate about causes and more about the damage that society is suffering because of the crisis of welfare. In fact, the debate is more about politicians and their corruptions, than about politics and democratic representation.

The space is also occupied on a local base. The concentrations are performed in front of Hospitals, Schools and workplaces in general. This dispersion is related to the purpose of demonstrations. In the case of 'PAH', they produce demonstrations in front of banks, and concentrations to avoid evictions. In general, spaces are strongly associated with the purpose 
of the claims. This is a marked difference in forms and occupations of the space in relation with the first wave. For example, there is a close relation between the contents of the protest and the spatial structure they adopt. The concentrations that ask for more democracy and transparency usually make use of public squares and sit in a big circle to debate. They shape a democratic and egalitarian concentration.

The protests articulated by the crisis of welfare (education, health, civil service, etc.) concentrate in front of their workplaces, on a periodic and regular basis. Protests against hypothecation law are itinerant and take place in banks or houses of political leaders (scratches). Socially, PAH is the most popular, low class oriented. PAH is always active and the level of commitment is high because they have to face the police and the legal force to avoid evictions. In comparison with the first wave, there is a change, the great diversity of these movements both in their demands and in their forms of protest. The set is a very diverse array of protests and demonstrations where, to some extent, the forms anticipate the content.

\section{Conclusions and expectations}

As we have seen, only using visual data is it possible to appreciate the real process that the Spanish Revolution has experienced. The evolving forms, the role of colors and the changes in the space occupations reflect the successive reactions to well-defined social shocks. When the real nature of the protests is revealed (by visual analysis), it is possible to evaluate how far the social structure can afford the high levels of 'structural violence' that suffers from the new forms of financial capitalism. Providers and consumers of welfare have articulated the second wave of protest. At least in the origin, the welfare pillars in the service sector have articulated the emerging conflicts. The deepness of the crisis may produce a new social structure that will be expressed in different ways. But at the very beginning, social responses will be articulated by the impacts of the crisis on the different sectors of welfare.

Only a collapse of the identity of middle class might produce an actual violent social conflict. But again, from a visual point of view, it is very likely that first we see a collapse of colors, showing the unification of fragmented identities. Nowadays, these reflexive identities are essentially based upon colors. This is because colors function as a provisional identity. At the same time, a new development in this crisis will need to offer an alternative identity system. If middle class identity falls (neither consumption nor welfare) 
something has to substitute the colors of claims in a new stage. But in the new phase of social conflicts, the 'reflexive modernization' very probably will reduce its impacts. Reflexivity, from the media point of view, is now under close supervision. Its effects on the social crisis in developed countries might have unexpected consequences.

\section{Bibliography}

Alaminos, A.; Penalva, C.; Domenech, Y. (2014), "Reacciones comunitarias a la crisis económica y social en España", in AZARBE-Revista Internacional de Trabajo Social y Bienestar, no. 3 .

Alaminos, A. and Penalva C. (2013), "España: de los impactos de la crisis a las movilizaciones de protesta", in Ecuador Debate, August.

Alaminos, Antonio and Penalva, Clemente (2011), "La vida cotidiana en España", in La Sociedad, edited by Salustiano Del Campo and José Félix Tezanos, Madrid: Biblioteca Nueva.

Aron, Raymon (1964), La Lutte des classes, Paris: Gallimard.

Bauman, Zygmunt (2000), Liquid Modernity, Cambridge: Polity Press.

Beck, Ulrich (1994), "The Reinvention of Politics", in The Reflexive Modernization. Politics, Tradition and Aesthetics in the Modern Social Order, edited by Ulrich Beck, Anthony Giddens and Scott Lash, Stanford: Stanford University Press.

Bourdieu, Pierre and Wacquant, Loïe (1992), Invitation to a Reflexive Sociology, Chicago: University of Chicago Press.

Chauvin, Pierre-Marie and Reix, Fabien (2013), 'Intérêts et difficultés de l'usage des ressources visuelles comme outils de recherche en sciences sociales', in Réjane HamusVallée (dir.), Sociologie de l'image, sociologie par l'image. Cinémaction, no. 147.

Dahrendorf, Ralf (1959), Class and Class Conflict in Industrial Society, Stanford: Stanford University Press.

Giddens, Anthony (1991), Modernity and Self-identity: Self and Society in the Late Modern Age, Stanford: Stanford University Press.

Giddens, Anthony (1994), 'Living in a Post-Traditional Society', in The Reflexive Modernization. Politics, Tradition and Aesthetics in the Modern Social Order, edited by Ulrich Beck, Anthony Giddens and Scott Lash, Stanford: Stanford University Press.

Pauwels, Luc (2011), "An integrated conceptual Framework for visual social research", in The Sage Handbook of Visual Research Methods, Eric Margolis and Luc Pauwels (Dir.), London: Sage.

Rieger, John H. (2011), "Rephotography for documenting social change", in The Sage Handbook of Visual Research Methods, Eric Margolis and Luc Pauwels (Dir.), London: Sage. 
Convergencia Revista de Ciencias Sociales, núm. 70, 2016, Universidad Autónoma del Estado de México

\section{Electronic resources}

Acampada Sol (2011), “Acampada Sol”. Avaliable at: https://www.flickr.com/ photos/63079840@N07/ [Consulted on:6 october 2014].

Conord, Sylvaine (2002), 'Le choix de l'image en anthropologie: qu'est-ce qu'une bonne photographie?, ethnographiques.org, 2 [http://www.ethnographiques.org/2002/ Conord - access 4.03.2014].

Contra la funcionario-fobia (2012), "No a la funcionario-fobia. Rechazamos la denostación permanente de nuestra imagen y nuestro trabajo". Available at: http:// noalafuncionariofobia.blogspot.com.es/ [Consulted on: October $6^{\text {th }}, 2014$ ].

Eldiario.es (2013), “Fotogalería: La 'marea verde' inunda Baleares”, in Eldiario.es, 13 May 2013. Available at: http://www.eldiario.es/sociedad/marea-verde-inundaBaleares_12_180701929.html [Consulted on: October 6th, 2014].

El País (2012a), "El aniversario del 15M, en fotos”. Available at: http://elpais.com/ elpais/2012/05/12/album/1336843844_764277.html\#1336843844_764277_1336 861946 [Consulted on: October 6th, 2014].

El País (2012b) "Protesta del Movimiento 15M". Available at: http://elpais.com/ elpais/2011/05/17/album/1305620219_910215.html\#1305620219_910215_0000 000000 [Consulted on: October 6th, 2014].

Fotospanishrevolution (2012), "Fotospanishrevolution.org" Available at: <http://www. fotospanishrevolution.org/photos.aspx? $\mathrm{view}=2>$ [Consulted on: October 6th, 2014].

Huffington Post (2013), "Miles de personas participan en Madrid en una 'marea blanca' en defensa de la sanidad pública (FOTOS)”, Huffington Post, April $21^{\text {st }} 2013$. Available at: http://www.huffingtonpost.es/2013/04/21/miles-de-personas-partici_1_n_3126505. html\#slide=2361751 [Consulted on: October 6th, 2014].

Marea Verde Granada (2013), "Album de Fotos”. Available at: http://mareaverdegranada. blogspot.com.es/p/blog-page.html [Consulted on: October 6th, 2014].

Marea Verde Sevilla (2012), "Fotos”. Available at: http://mareaverdesevilla.blogspot.com. es/p/fotos_15.html [Consulted on: October 6th, 2014].

Martín, Uly (2013), "Protagonistas de la 'Marea Blanca”, in El País, September $22^{\text {nd }}, 2013$. Available at: http://sociedad.elpais.com/sociedad/2013/09/22/ album/1379867248_757396.html\#1379867248_757396_1379867896 [Consulted on: February $\left.16^{\text {th }}, 2015\right]$.

PSOE Región de Murcia (2013), “Marea blanca”. Available at: https://www.flickr.com/ photos/psrm/sets/72157637057460695/ [Consulted on: February 16th, 2015].

Ryukenichi (2011), “Homepage”. Avaliable at: http://ryukenichi.files.wordpress. com/2011/05/15m.jpg [Date of the last recovery: 6 october 2014].

Totally Cool Pix (2011), “The Spanish Protest”. Available at:http://totallycoolpix.com/ magazine/2011/05/the-spanish-protests [Consulted on: October 6th, 2014].

Viernes de luto (2012), “Fotos”. Available at: https://www.facebook.com/viernesdeluto/ photos_stream [Consulted on: February 16th, 2015]. 


\section{Annex}

\section{Table 1}

\section{The evolution of the Spanish Revolution}

\begin{tabular}{|c|c|c|}
\hline & $\begin{array}{l}\text { FIRST WAVE } \\
\text { (15 of May 2011-20 } \\
\text { November 2011) }\end{array}$ & $\begin{array}{l}\text { SECOND WAVE } \\
\text { (20 November } 2011 \text {-nowadays) }\end{array}$ \\
\hline Shock & $\begin{array}{l}\text { Economic crisis: } \\
\text { unemployment }\end{array}$ & Welfare crisis \\
\hline Main claims & Causes & Consequences \\
\hline Spatially & United & Diversity \\
\hline Actions & $\begin{array}{l}\text { Occupy public squares } \\
\text { (Symbolic meaning) }\end{array}$ & $\begin{array}{l}\text { Demonstrations and } \\
\text { concentrations in front of } \\
\text { workplaces (Functional) }\end{array}$ \\
\hline Contents & Heterogeneity & Specialized \\
\hline $\begin{array}{l}\text { Mass media } \\
\text { approach }\end{array}$ & $15 \mathrm{M}$ as novelty news & News about the $15 \mathrm{M}$ \\
\hline $\begin{array}{l}\text { Mass media } \\
\text { coverage }\end{array}$ & Massive and continued & Punctual and limited \\
\hline Reflexivity & $\begin{array}{l}\text { Surprise as unexpected } \\
\text { consequence }\end{array}$ & Regular calls \\
\hline Expressions & Textual (slogans) & Colors \\
\hline Supports & Posters, pamphlets & T-shirts, caps, graffiti \\
\hline Social reaction & $\begin{array}{l}\text { Communitarian organization } \\
\text { of Societal claims }\end{array}$ & $\begin{array}{l}\text { Societal organization of } \\
\text { Communitarian claims }\end{array}$ \\
\hline Social ties & Emotions & Demonstrations \\
\hline Identity & $\begin{array}{l}\text { Identity of the system: } \\
\text { democracy, consume, etc. }\end{array}$ & $\begin{array}{l}\text { Self and class identity: out of } \\
\text { middle class }\end{array}$ \\
\hline
\end{tabular}

Source: authors' own analysis of visual data. 


\section{Table 2}

\section{Sources of visual data. First wave}

\section{Social media sites:}

Collective website: Fotospanishrevolution.org. (2012) (collaborative photo project) with an index by authors

Photo Gallery of Acampada Sol (2011)

Personal blog of Ryukenichi (2011)

\section{Conventional media:}

El País (2012a, 2012b), Photo albums of digital newspaper El País (News agency professionals)

Totally Cool Pix website (2011) (Reuters photographs)

\section{Table 3}

\section{Sources of visual data. Second wave}

\section{Conventional media}

Green Tide. Eldiario.es (2013), Photo-gallery of digital newspaper eldiario.es

White Tide. Hufftington Post (2013), Digital newspaper and news aggregator

White Tide. Martín (2013), Photo-gallery of digital newspaper El País

\section{Social Media}

Green Tide. Marea Verde Granada (2013), Organization blog

Green Tide. Marea Verde Sevilla (2012), Organization blog

Black Tide. Contra la funcionario-fobia (2012), Civil Servant organization blog:

Black Tide. Viernes de luto (2012), Facebook group

White Tide. PSOE Región de Murcia (2013), Flickr

Antonio Alaminos Chica. University Professor, Doctor in Sociology, Director of the Department of Sociology II. University of Alicante, Spain. Research lines: consumption society and social position: the crises of middle classes; management of quotidian uncertainties (labor, health, education; etc.) after the Welfare State; legitimation of new inequalities from politicaleconomic discourses. Recent publications: "Reacciones comunitarias 
a la crisis económica y social en España", in revista $A z a r b e$ (with Antonio Alaminos and Yolanda Domenech) (2014); "Las clases medias en Europa: estatus y poder en el siglo XXI", in SocietàMutamentoPolitica (2013); "La futura vida cotidiana en España: la sociedad de consumo”, in OBETS. Revista de Ciencias Sociales (2013).

Clemente Penalva Verdú. Titular professor. Doctor in Sociology. Department of Sociology II and researcher in the Inter-university Institute of Social Development and Peace. University of Alicante, Spain. Research lines: social capital and social mobilization; mutual support networks and networks for political action; economic dimension of social trust: reciprocity, promise and debt. Recent publications: "Reacciones comunitarias a la crisis económica y social en España", in revista Azarbe (with Antonio Alaminos and Yolanda Domenech) (2014); "España: de los impactos de la crisis a las movilizaciones de protesta", in Ecuador Debate (with Antonio Alaminos) (2013); "The cognitive mobilization index: crises and political generations", in Sage Open (with Antonio Alaminos) (2012).

Reception: April 20 2015

Approval: November 2th, 2015 
